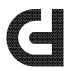 \\ COUNTERFUTURES \\ Left thought \& practice Aotearoa
}

\section{THREE}




\title{
The evil of the lesser evil
}

\author{
Tim Corballis
}

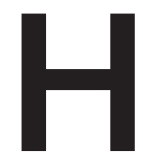

ERE IS ONE casualty: the scale on which we locate political identities. Trump did not kill it—it has been ailing for several decades-but his election is a sign among others of its decline. In troubling the Left-Right spectrum, Trump joins not just the Brexiters and other populists, but also weirder figures like Proudhon- and Foucault-reading, gun toting (and printing) libertarian anarchist Cody Wilson, and indeed the Israeli Defence Force, enthusiastic readers of the Situationists. It is no longer so easy to place ourselves on that continuum, and our measure of the distance between the two presidential candidates reveals the danger in doing so.

Trump hates women (his word for it: love). He more openly hates immigrants and other minorities. He is torture happy and fond of walls. These things are enough to raise our horror. He has played a huge part in a shift in what is publicly sayablein a dismantling of the common standards of censorship. If this 
licensing of prejudice leads to a similar shift in what is publicly doable, then this is truly frightening. In the age of finance capital, what is said already has performative magic: shares in weapons manufacture and private prisons have responded accordingly to Trump's victory. But Trump, like Rousseau, also loves the people. Like the Green Party, he is against the TPPA. Unlike the (slightly) more hawkish Clinton, he is opposed to US imperial hegemony, if ambiguously, preferring to keep 'greatness' at home. In echoes of the New Deal, he wants to build infrastructure, create jobs and raise the minimum wage.

It is not surprising that any single figure, especially one so given to non-sequitur, might be with us on some things, against us on others. The projection of political constellations onto a single dimension has always been imperfect. In this situation, however, the very idea of the Left-if we understand it as a portion of a spectrum, the other end from the Right-easily forces us into thoughts of greater and lesser evils, of positions closer to us and further from us on that line, the judgments and competitive leftisms of 'more left' and 'more right'. According to this logic, Clinton for her attachment to bombs and capital is surely closer to us. It is this that can have us cleave strongly, time after time, to the status quo, for fear of the latest monster on the other side. It is this that can have us only ever support the moderately lesser evil in the hope of moving it leftward.

The greatest evil of all, though, might just be the need always to prefer the lesser evil. For the left, one task is the creation of new measures, new cognitive mappings of the political terrain. Analytically, I have wondered in the past year whether 'Left vs. Right' might be a less instructive axis than 'post-politics vs anti-politics': the insider, institutional, and technocratic consensus that does not tolerate uninformed political opposition, and against it the rage of those who have been left out of the whole deal and would wipe it away with a gesture. This is a field 
that steps to either side of what we have hitherto known as 'politics', marked by the Left-Right spectrum itself.

More nuanced is Nancy Fraser's tripartite Polanyian distinction between marketisation, emancipation and social protection. If Clinton represents emancipation-the continual openness to 'others' - it is only in the form of its current alliance with marketisation and its eschewal of social protection. It is up to a Trump (or, perhaps, an al-Baghdadi) to gather up the remains of social protection for those without access to the benefits of accumulation, and to recognise the enemy: the alliance itself, markets, and emancipation together. The solution, of course, is to break the alliance and form another: emancipation and social protection against marketisation.

Such formulations allow the Left not to take the preexisting sides. This is not quite the same as refusing the whole edifice of media, elections and representatives. It means distancing ourselves from the ways in which the single measure structures political imagery: the labelling of candidates, the colouring of maps. Parliaments themselves have become, among other things, spatial expressions of the measure - the great, schematic $\mathrm{U}$ of seats in the house, with its balance point, the target for parties chasing a majority. What other forms of mapping are there that do not orient us again and again towards swing states, undecided voters, single issues, small anchors on the slippery slope, the vanishing points of the political?

January 2017 
If you like what you have read, please subscribe or donate.

\author{
G \\ COUNTERF UTURES \\ Left thought \& practice Aotearoa \\ (C) Copyright Counterfutures 2017
}

